\title{
Heterotypic reactions in a radioimmunoassay for coxsackie B virus specific IgM
}

\author{
SF PUGH
}

From the Virus Reference Laboratory, Central Public Health Laboratory, Colindale Avenue, London NW9 $5 H T$

SUMMARY IgM antibody capture radioimmunoassays were developed to detect coxsackie virus B1-B5 specific IgM. Specific IgM was detected in sera from all patients with coxsackie B virus infections proved by isolation; however, sera from $13 / 32$ patients with rising neutralising antibody titres were negative in the assay. Frequent heterotypic responses were seen among the positive sera. Thirty seven patients with other enterovirus infections were also studied, and sera from 15 of these patients reacted in the assay, showing that heterotypic coxsackie B IgM responses occur not only in coxsackie B virus infections but also in other enterovirus infections.

Coxsackie $B$ viruses have been implicated in a number of serious infections of the myocardium and pericardium. Coxsackie $\mathrm{B}$ virus is rarely isolated in these conditions, however, and serological diagnosis by the neutralisation test has proved unsatisfactory.

Specific IgM antibody has been found in patients with coxsackie $B$ virus infections using neutralising antibody and 2-mercaptoethanol treatment ${ }^{\prime}$ and immunoelectrophoresis. ${ }^{2}$ These methods, however, are not suitable for routine diagnostic use. Recently, El-Hagrassy et al $^{3}$ showed that an IgM antibody capture enzyme assay could detect coxsackie B specific IgM in patients with recent infections and in some patients with heart disease. These authors used a mixed antigen containing coxsackie $\mathrm{B}$ virus types $1-5$, however, and therefore heterotypic reactions within the group could not be investigated. Furthermore, sera from patients with other enterovirus infections were not studied.

The object of this study was to establish whether an IgM antibody capture radioimmunoassay (MACRIA) could be used to diagnose recent coxsackie $B$ virus infections using individual antigens and to investigate heterotypic reactions within the group and in other enterovirus infections.

\section{Material and methods}

MATERIALS

Assay control sera

These were found by trial and error during the

Accepted for publication 7 December 1983 development of the method since at the time there was no source of proved coxsackie B IgM positive or negative material.

The positive control serum was obtained by screening a number of sera with rising coxsackie $B$ neutralising antibody titres for virus specific IgM. One was selected which reacted strongly with all five of the coxsackie B antigens, allowing the use of a single serum as the positive control.

The negative control serum was obtained by screening several units of recalcified plasma from healthy blood donors. None reacted in the assay, and one of the units was selected as the negative control.

\section{Specimens from control patients}

Twenty consecutive sera sent for routine syphilis serology from adult patients (mean age 50 years (range 25-82)) admitted to a psychiatric hospital and 20 sera collected from well children (mean age 7.5 years (range 3-12)) admitted to hospital for routine orthopaedic operations were used as control sera.

Specimens from patients with enterovirus infections Thirty two paired sera were obtained from patients (mean age 31 years (range 1-60)) with fourfold or greater rises in coxsackie B neutralising antibody titre to one or more serotypes. Sera from 11 patients (mean age 10 years (range 1-30)) from whom coxsackie $B$ virus was isolated and paired sera from 37 patients (mean age 15 years (range 1-47)) from whom other enteroviruses had been isolated were also obtained. 
Virus antigens

Prototype coxsackie B1 and B5 viruses (obtained from Dr DR Gamble, Public Health Laboratory, Epsom) were propagated in VERO cells, which were harvested by freezing and thawing three times when $100 \%$ of cell monolayers showed cytopathic effects. The antigens were clarified by centrifugation at $3000 \mathrm{~g}$ and stored in aliquots at $-20^{\circ} \mathrm{C}$. Control antigen was similarly prepared from cell lysates from uninfected VERO cells. The antigens were assayed for infectivity in cell cultures. The coxsackie B2 antigen has a titre of $10^{7} \mathrm{TCID}_{50} / \mathrm{ml}$ and the other antigens a titre of $10^{7 \cdot 5} \mathrm{TCID}_{50} / \mathrm{ml}$.

\section{Antiserum production}

Antisera to coxsackie B1 to B5 were raised in New Zealand white rabbits. The animals were inoculated intravenously initially with $1 \mathrm{ml}$ of clarified antigen and boosted with $2 \mathrm{ml}$ of antigen at 4,13 , and 14 weeks. They were bled 10 days after the last booster injection. These antisera were suitable for MACRIA except for the coxsackie B4 antiserum. A satisfactory antiserum against this serotype (batch no 1/65) was obtained from the Division of Microbiological Reagents and Quality Control, Central Public Health Laboratory, Colindale.

\section{Radiolabelled antirabbit IgG}

A $10 \mu \mathrm{g}$ sample of affinity purified goat antirabbit IgG (TAGO) was labelled with $0.25 \mathrm{mCi}$ of ${ }^{125} \mathrm{I}$ by the iodogen method. ${ }^{4}$ Free iodine was separated by fractionation on a Sephadex G25 column (Pharmacia Ltd).

\section{ASSAY}

A solid phase IgM capture method (MACRIA) was used. Briefly, polystyrene beads coated with antibody to human IgM were incubated with patients' sera. After washing away unbound serum components, the beads were incubated with the coxsackie $B$ virus antigens. Any coxsackie B virus specific IgM on the beads would bind the antigen, which was then detected using unlabelled rabbit coxsackie $B$ antisera followed by a radiolabelled antirabbit IgG antiserum.

The test was performed in Abbott 20 well reaction trays using $6.5 \mathrm{~mm}$ etched polystyrene balls (Northumbria Biologicals) for the solid phase. The beads were washed three times between each stage of the test with phosphate buffered saline containing $0.05 \%$ TWEEN 20 . The diluent for all stages of the test was phosphate buffered saline with $0.05 \%$ TWEEN 20 and $10 \%$ fetal calf serum and the reaction volume was $0.2 \mathrm{ml}$.

The beads were coated overnight at $+4^{\circ} \mathrm{C}$ with goat antihuman $\mu$-chain specific affinity purified antibody (TAGO) diluted $1 / 2000$ in $0.05 \mathrm{M}$ carbonate-bicarbonate buffer pH 9.6 using $0.2 \mathrm{ml}$ per bead. The beads were then washed and distributed into the reaction wells, and test sera diluted $1 / 100$ was added and incubated at $37^{\circ} \mathrm{C}$ for $2 \mathrm{~h}$. At this stage the antigens, diluted $1 / 2$, were added and incubated for $18 \mathrm{~h}$ at room temperature. The sera were tested against coxsackie B serotypes 1-5 and control antigen. After this the rabbit coxsackie B antisera diluted 1/3000 in diluent were added and incubated for $2 \mathrm{~h}$ at $37^{\circ} \mathrm{C}$. Finally, the labelled goat antirabbit IgG diluted to 25000 counts $/ \mathrm{min} /$ well was added and incubated at $37^{\circ} \mathrm{C}$ for $2 \mathrm{~h}$. After final washing the beads were transferred to tubes and counted for 300 s on a Nuclear Enterprises 1600 gamma counter. Positive and negative control sera were tested for each antigen. The results were expressed as the ratio between the counts from the test serum and those of the negative contol serum ( $\mathrm{P} / \mathrm{N}$ ratio)

\section{Results}

\section{METHOD}

Fig. 1 shows the level of binding in a titration of the

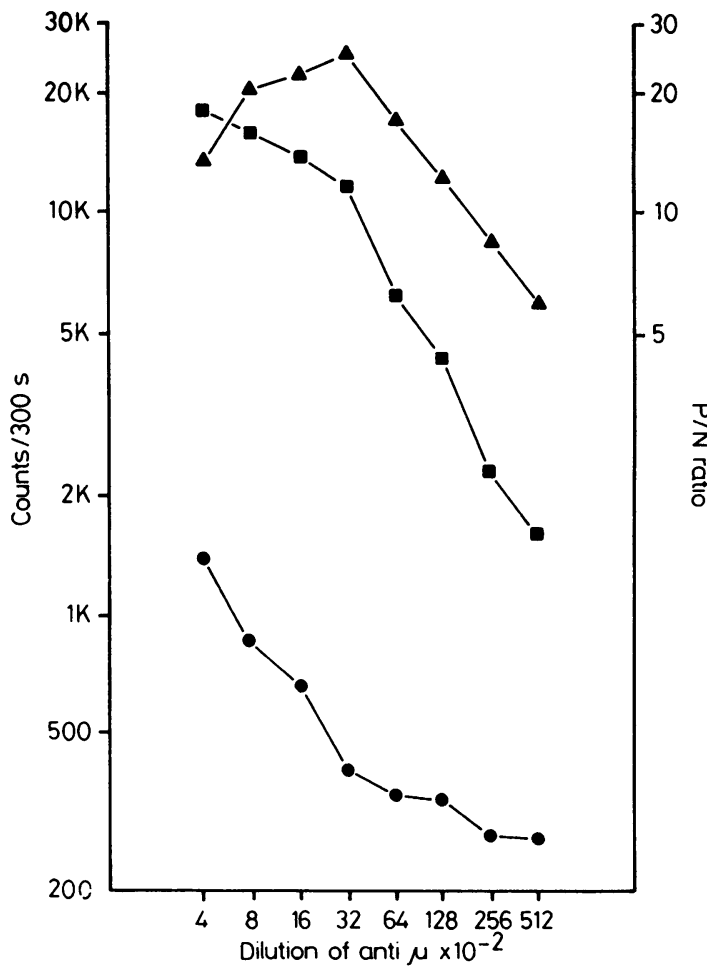

Fig. 1 Titration of anti $\mu$-coating serum using positive ( $\square$ ) and negative (๑) contol sera at $1 / 100$ and coxsackie BI antigen at 1/2.P/N ratios $(\Delta)$ are also shown. 
antihuman $\mu$-chain coating serum in the MACRIA test using positive and negative control sera. A positive control $\mathrm{P} / \mathrm{N}$ ratio of about 20 and a label binding of about $8 \%$ were obtained at the optimum coating dilution. The positive control serum which was broadly reactive gave similar ratios for all serotypes. The positive control serum was tested at dilutions from $1 / 100$ to $1 / 51200$ (Fig. 2). The highest P/N ratios were found at $1 / 100-1 / 200$, but specific activity was still detected at $1 / 51200$. The antigens were tested at dilutions from neat to $1 / 512$ using positive control serum at $1 / 100$. The $P / N$ values fell off rapidly at dilutions greater than $1 / 4$ (Fig. 3). All these experiments were performed with the five antigens with very similar results, but only the B1 results are shown for clarity.

The rabbit antisera used for antigen detection were type specific in this assay. A chessboard titration was set up testing each rabbit antiserum against each coxsackie $B$ antigen, using anti- $\mu$-chain coated beads previously incubated with positive control serum to bind the antigen. The results for each antiserum were expressed as a percentage of the binding to homologous antigen. The heterotypic binding of each antiserum was in all cases $10 \%$ or less of its binding to homologous antigen (Table 1).

CONTROL SERA

The mean $\mathrm{P} / \mathrm{N}$ values for each coxsackie B serotype

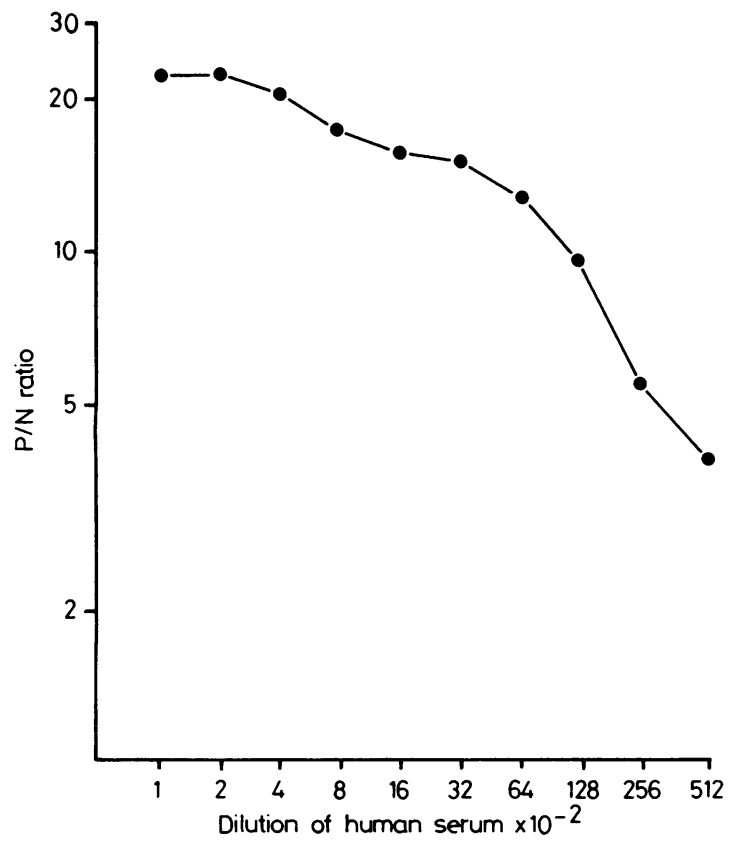

Fig. 2 Titration of the positive control serum in the MACRIA using coxsackie BI antigen at $1 / 2$.

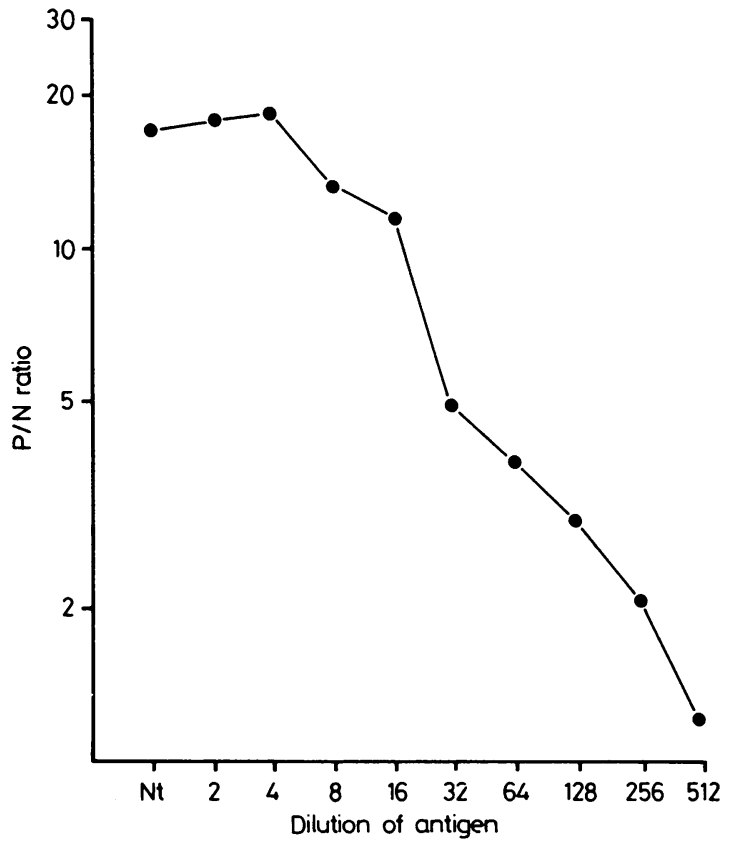

Fig. 3 Titration of coxsackie B1 antigen in the MACRIA using the positive control serum at 1/100.

obtained from the control groups are shown in Table 2. As enterovirus infections are extremely common some positive results were expected among these sera, especially from children.

The mean $\mathrm{P} / \mathrm{N}$ values +2 standard deviations did not exceed 3 for any serotype in the adult sera. This value was exceeded only for $\mathrm{B} 5$ in the sera from healthy children. One of these sera gave a $\mathrm{P} / \mathrm{N}$ ratio of 7 for B5, which distorted the result for this serotype. Accordingly, a P/N ratio of 3 was selected as the cut off point for the purposes of this study. None of the control or test sera in this study reacted with control antigen.

\section{COXSACKIE B INFECTIONS}

The initial work with this test was done with sera showing fourfold rises in neutralising antibody titre

Table 1 Percentage binding* of rabbit coxsackie $B$ virus antisera to different antigens

\begin{tabular}{|c|c|c|c|c|c|}
\hline \multirow[t]{2}{*}{ Antisera } & \multicolumn{5}{|c|}{ Coxsackie antigens } \\
\hline & $B 1$ & $B 2$ & B3 & $B 4$ & B5 \\
\hline $\begin{array}{l}\text { Coxsackie B1 } \\
\text { Coxsackie B2 } \\
\text { Coxsackie B3 } \\
\text { Coxsackie B4 } \\
\text { Coxsackie B5 }\end{array}$ & $\begin{array}{r}100 \\
1 \\
8 \\
7 \\
4\end{array}$ & $\begin{array}{r}2 \\
100 \\
3 \\
9 \\
2\end{array}$ & $\begin{array}{r}9 \\
7 \\
100 \\
10 \\
9\end{array}$ & $\begin{array}{r}<1 \\
<1 \\
<1 \\
100 \\
1\end{array}$ & $\begin{array}{r}4 \\
<1 \\
2 \\
4 \\
100\end{array}$ \\
\hline
\end{tabular}


Table 2 Geometric mean $P / N$ values for the control sera $( \pm 2 S D)$

\begin{tabular}{lll}
\hline Serotype & Healthy adults & Healthy children \\
\hline B1 & $0.91(0.49-1 \cdot 7)$ & $0.93(0.61-1.4)$ \\
B2 & $1 \cdot 05(0.77-1.4)$ & $1 \cdot 16(0.07-1.9)$ \\
B3 & $1 \cdot 16(0.46-2.9)$ & $1.01(0.07-1.4)$ \\
B4 & $1.03(0.05-2 \cdot 1)$ & $1 \cdot 27(0.64-2 \cdot 5)$ \\
B5 & $0.75(0.42-1.3)$ & $1 \cdot 16(0.38-3.6)$ \\
\hline
\end{tabular}

to one or more coxsackie B serotypes. The IgM responses in these sera were extremely varied and the correlation between rising neutralising antibody titres and the MACRIA responses was not good (Table 3). Only $9 / 21$ sera with monotypic rising neutralising antibody titres were positive by MACRIA, but of the MACRIA positive sera 8/9 contained IgM which reacted with the same serotype as the neutralising antibody rise. There were 11 sera with rising neutralising antibody titres to two or more serotypes, and all but one of these was MACRIA positive.

Sera from 11 patients from whom coxsackie B viruses were isolated were studied. The difference between these and the rising titre sera was striking (Table 4). All the sera were IgM positive compared with only $60 \%$ of the rising titre sera. All of them reacted with the serotype isolated, but heterotypic responses were also seen. No sera from patients with established coxsackie B5 infections were available for study.

\section{OTHER ENTEROVIRUS INFECTIONS}

Paired sera from 37 patients with other enterovirus infections were studied in order to investigate crossreactions outside the coxsackie $B$ group.

Eighteen of 37 of the convalescent sera reacted in the coxsackie B MACRIA. The distribution of IgM positive results appeared similar to that found with the rising titre sera (Table 5), and the $\mathrm{P} / \mathrm{N}$ ratios obtained were of a similar order. All but three of the IgM positive enterovirus sera showed an increase in $\mathrm{P} / \mathrm{N}$ ratio between the acute and convalescent sera. In two of the three patients who showed no change in IgM concentration the acute serum was taken relatively late, at five and eight days after onset. In the other patient the acute serum was taken on the first day of illness and in this case the IgM detected may have been due to a previous infection.

Heterotypic responses were more common (5/6) in the coxsackie $A$ virus infections than the echovirus infections (13/30), but there did not seem to be any relation between the enterovirus serotype isolated and the serotype of the responses in the

Table 3 MACRIA results in convalescent sera from patients with rising neutralising antibody titres to coxsackie B viruses

\begin{tabular}{|c|c|c|c|c|c|c|c|c|}
\hline \multirow[t]{2}{*}{ Patient } & \multirow{2}{*}{$\begin{array}{l}\text { Fourfold rises } \\
\text { to coxsackie }\end{array}$} & \multirow[t]{2}{*}{ Diagnosis } & \multirow{2}{*}{$\begin{array}{l}\text { Age } \\
(y r)\end{array}$} & \multicolumn{5}{|c|}{$M A C R I A$ results } \\
\hline & & & & $B 1$ & $B 2$ & $B 3$ & $B 4$ & $B 5$ \\
\hline$\overline{\mathrm{MF}}$ & B2 & Fever + headache & 38 & - & + & - & + & - \\
\hline MC & B2 & Fever + rash & 17 & + & + & + & + & + \\
\hline $\mathrm{AH}$ & B2 & Meningism & NK & + & + & + & + & + \\
\hline MB & B2 & Lymphadenopathy & 20 & - & - & - & - & - \\
\hline RC & B2 & PUO & 45 & - & - & - & + & - \\
\hline RS & B2 & Pancreatitis & NK & - & - & - & - & - \\
\hline $\mathrm{CC}$ & B3 & Sore throat & 8 & - & - & + & + & - \\
\hline SW & B3 & Pericarditis & 50 & - & - & - & - & - \\
\hline SF & B3 & Bornholm disease & NK & - & - & - & - & - \\
\hline $\mathrm{JH}$ & B3 & Pericarditis & 48 & - & - & - & - & - \\
\hline $\mathbf{K N}$ & B3 & Pneumonia & 60 & - & - & - & - & - \\
\hline JG & B3 & Pericarditis & 25 & - & - & - & - & - \\
\hline JC & B3 & SBE & 55 & - & + & + & + & - \\
\hline SK & B4 & Pericarditis & 36 & - & - & - & - & - \\
\hline MD & B4 & Chest pain & 17 & - & - & - & - & - \\
\hline $\mathrm{CE}$ & B4 & Diabetic & 15 & - & - & - & + & - \\
\hline SR & B4 & Chest pain & 32 & - & - & - & + & - \\
\hline JW & B4 & Chest pain & 39 & - & - & - & + & - \\
\hline MC & B4 & Muscle pain & 34 & - & - & - & - & - \\
\hline DS & B5 & Cellulitis of hand & 1 & - & - & - & - & - \\
\hline BD & B5 & Pericarditis & 50 & - & - & - & - & - \\
\hline BS & B2 B4 & Pleurodynia & 51 & - & - & - & + & - \\
\hline $\mathbf{A M}$ & B3 B5 & Meningitis & NK & + & - & - & - & - \\
\hline JK & B3 B4 & NK & NK & + & + & + & + & - \\
\hline SB & B2 B3 & Bornholm disease & 16 & - & + & + & + & - \\
\hline JL & B4 B5 & Pericarditis & 53 & - & - & - & - & - \\
\hline $\mathrm{JC}$ & B4 B5 & Chest pain & 13 & + & + & + & + & + \\
\hline LW & B1 B4 B5 & Chest pain & 10 & - & - & + & + & - \\
\hline SJ & B2 B3 B4 & Myositis & 34 & + & + & + & + & + \\
\hline EW & B2 B3 B6 & Pericarditis & 51 & + & + & + & - & + \\
\hline WM & B2 B3 B4 B6 & Convulsions & 6 & + & + & + & + & + \\
\hline JH & B1 B2 B4 B5 B6 & Bornholm disease & 12 & - & + & - & + & + \\
\hline
\end{tabular}

NK = not known; PUO = pyrexia of unknown origin; SBE = subacute bacterial endocarditis. 
Table 4 MACRIA results in sera from patients from whom coxsackie $B$ virus was isolated

\begin{tabular}{|c|c|c|c|c|c|c|c|c|}
\hline \multirow[t]{2}{*}{ Patient } & \multirow{2}{*}{$\begin{array}{l}\text { Coxsackie } \\
\text { isolates }\end{array}$} & \multirow[t]{2}{*}{ Diagnosis } & \multirow{2}{*}{$\begin{array}{c}\text { Age } \\
(y r)\end{array}$} & \multicolumn{5}{|c|}{$M A C R I A$ results } \\
\hline & & & & $B 1$ & $B 2$ & B3 & $B 4$ & $B 5$ \\
\hline JM & B1 & Meningitis & 30 & + & + & - & - & - \\
\hline RO & B2 & NK & NK & - & + & - & - & - \\
\hline CF & B3 & NK & NK & + & - & + & - & - \\
\hline WL & B3 & Chest pain & 10 & - & - & + & + & - \\
\hline TW & B4 & Pyrexia, malaise & 30 & - & - & - & + & - \\
\hline ST & B4 & Myocarditis & 1 & - & - & - & + & - \\
\hline CD & B4 & Cough + fever & 2 & - & - & - & + & - \\
\hline $\mathbf{R L}$ & B4 & Diarrhoea & 1 & - & - & - & + & - \\
\hline JT & B4 & Meningitis & 5 & - & - & + & + & - \\
\hline SK & B4 & Diarrhoea + vomiting & 2 & + & - & + & + & + \\
\hline DS & B4 & Leukaemia & NK & + & + & + & + & + \\
\hline
\end{tabular}

NK = not known.

coxsackie B MACRIA. For example, five sera were studied from patients with coxsackie A9 infections. One of these was negative in the MACRIA, one made a monotypic response to coxsackie B1, another reacted with $\mathrm{B} 5$, and the remainder reacted with three or more serotypes. Of the 11 sera studied from patients with echo 30 virus infections, seven were negative in MACRIA, one made a monotypic response to coxsackie $B 3$, another reacted with $B 5$, and the remainder reacted with two or more coxsackie B serotypes.

Table 5 MACRIA results in convalescent sera from patients from whom other enteroviruses were isolated

\begin{tabular}{|c|c|c|c|c|c|c|c|c|}
\hline \multirow[t]{2}{*}{ Patient } & \multirow[t]{2}{*}{ Isolate } & \multirow[t]{2}{*}{ Diagnosis } & \multirow{2}{*}{$\begin{array}{c}\text { Age } \\
\text { (yr) }\end{array}$} & \multicolumn{5}{|c|}{ MACRIA result } \\
\hline & & & & $B 1$ & $B 2$ & $B 3$ & $B 4$ & $B 5$ \\
\hline$\overline{\mathrm{LL}}$ & Echo 6 & ? Bornholm & 9 & - & - & - & - & - \\
\hline $\mathrm{JC}$ & Echo 6 & Meningitis & 20 & _- & - & - & - & - \\
\hline GS & Echo 6 & Meningitis & 10 & - & + & - & + & - \\
\hline JK & Echo 7 & Meningitis & 1 & - & - & - & - & - \\
\hline EM & Echo 7 & Flu meningism & 27 & - & - & - & - & - \\
\hline LR & Echo 7 & Meningitis & 15 & - & - & - & - & - \\
\hline LC & Echo 9 & Meningitis & 24 & - & - & - & - & - \\
\hline GR & Echo 9 & NK & 1 & - & - & - & - & - \\
\hline $\mathrm{CN}$ & Echo 9 & ? Measles & 2 & + & - & - & - & - \\
\hline $\mathbf{C M}$ & Echo 11 & URTI & 11 & - & - & - & - & - \\
\hline JM & Echo 11 & Meningitis & 19 & - & - & - & - & - \\
\hline MG & Echo 11 & Meningitis & 3 & - & - & - & _- & - \\
\hline MC & Echo 11 & Meningitis & 30 & + & + & + & + & - \\
\hline $\mathrm{CL}$ & Echo 11 & Meningitis & 29 & + & + & + & + & + \\
\hline HB & Echo 17 & Meningitis & 13 & - & + & - & - & - \\
\hline AN & Echo 17 & Influenza & 12 & + & - & - & - & + \\
\hline $\mathbf{K M}$ & Echo 24 & Meningitis & 11 & - & - & - & + & + \\
\hline $\mathbf{M A}$ & Echo 24 & Meningitis & 33 & + & + & + & + & + \\
\hline GM & Echo 24 & Meningitis & 47 & + & + & + & + & + \\
\hline $\mathrm{GH}$ & Echo 30 & Meningitis & 13 & - & - & - & - & - \\
\hline DM & Echo 30 & Meningitis & 11 & - & - & - & - & - \\
\hline DL & Echo 30 & $\mathrm{D}+\mathrm{V}$ meningism & 1 & - & - & - & - & - \\
\hline$\overline{\mathbf{M L}}$ & Echo 30 & Meningitis & 22 & - & - & - & - & - \\
\hline $\mathrm{HC}$ & Echo 30 & Meningitis & 40 & - & - & - & - & - \\
\hline$S E$ & Echo 30 & Meningitis & 8 & - & - & - & - & - \\
\hline JW & Echo 30 & Meningitis & 9 & - & - & - & - & - \\
\hline $\mathrm{DD}$ & Echo 30 & Meningitis & 22 & - & - & + & - & - \\
\hline JD & Echo 30 & Flu meningism & 1 & - & - & - & - & + \\
\hline SQ & Echo 30 & Meningitis & 7 & - & - & - & + & + \\
\hline DB & Echo 30 & Meningitis & 27 & + & + & - & + & + \\
\hline DG & Polio 2 & URTI, D + V & 1 & - & - & - & - & - \\
\hline$\overline{G B}$ & Cox A6 & Meningitis & NK & - & + & - & + & + \\
\hline $\mathrm{JC}$ & Cox A9 & Pyrexia & 2 & - & - & - & - & - \\
\hline SH & Cox A9 & ? Bornholm & 28 & + & - & - & - & - \\
\hline PD & Cox A9 & Meningitis & 4 & + & - & + & + & - \\
\hline $\mathrm{AB}$ & Cox A9 & Meningitis & 6 & + & + & + & + & + \\
\hline LD & Cox A9 & Myalgia & 10 & + & + & + & + & + \\
\hline
\end{tabular}

NK = not known; URTI = upper respiratory tract infection; D + V = diarrhoea + vomiting; Echo = echovirus; Polio = poliovirus; Cox $=$ Coxsackie virus. 


\section{Discussion}

This study has shown that the coxsackie B MACRIA can detect specific IgM in patients with recent coxsackie B virus infections. The cut off point chosen in this study, however, was based on the results obtained from a relatively small number of healthy children and adults and may not reflect a clinically important value. To determine this would require a study with larger numbers of specimens analysed by season, together with studies of positive sera taken sequentially to establish the duration of the IgM response.

Coxsackie B specific IgM was found in all the sera from patients from whom coxsackie $B$ viruses were isolated; it was also detected, however, in $48 \%$ of the sera from patients with other enterovirus infections. This is a major problem since the assay is neither specific for the coxsackie B virus group, nor will it detect all enterovirus infections. The responses in the MACRIA varied from monospecific to reactions with five different serotypes. In addition, monospecific coxsackie B IgM was seen in some patients with other enterovirus infections, suggesting that the heterotypic response is not simply group specific, which would presumably affect all serotypes, but also contains type specific antibodies.

The problem of heterotypic antibody responses in enterovirus serology has been recognised for many years. Heterotypic neutralising antibody responses have been seen in coxsackie $B$ virus infections ${ }^{5}$ and echovirus infections. ${ }^{6}$ Furthermore, heterotypic neutralising antibody responses across the coxsackie $B$ and echovirus groups have been shown in monkeys infected sequentially with different enteroviruses. ${ }^{7}$ An example of heterotypic boosting of coxsackie $B$ neutralising antibody by coxsackie A9 infection was seen in the present study. These data show that type specific neutralising antibody can be boosted not only by other coxsackie $B$ virus infections but also by other enterovirus infections.

Heterotypic coxsackie B IgM antibody responses have been seen using neutralising antibody and 2-mercaptoethanol treatment,' immunodiffusion, ${ }^{8}$ countercurrent immunoelectrophoresis, ${ }^{2}$ indirect solid phase enzyme immunoassay, ${ }^{9}$ and two IgM capture assays. ${ }^{10} 11$ This study has confirmed these findings and also that heterotypic boosting of coxsackie B IgM by other enterovirus infections, particularly coxsackie $A$, is common. ${ }^{10} 11$ The extensive heterotypic boosting of coxsackie B IgM as a result of enterovirus infection is a little surprising. Presumably it represents a secondary type of response and might therefore be expected to affect IgG antibody predominantly.

It is likely that the heterotypic responses depend on the previous exposure of the patient to enteroviruses and should therefore be related to age. Young children with fewer previous enterovirus infections would be expected to make a more specific response than older children or adults. Too few sera from young children were available in this study to establish this, but the work of King et al "1 suggests that it is so.

A striking finding in this study was that $40 \%$ of the sera with rising coxsackie $B$ neutralising antibody titres were negative in the MACRIA. There may be several explanations for this finding. The sensitivity of the MACRIA may be insufficient, although this seems unlikely. The sera could be from patients with reinfections, which might result in little IgM response. This also seems unlikely in view of the fact that all the sera from patients from whom coxsackie $B$ viruses were isolated were IgM positive, and coxsackie $\mathrm{B}$ IgM is boosted by other enterovirus infections. A third possibility is that the sera were from patients with other enterovirus infections which had boosted the coxsackie B neutralising antibody titre non-specifically. Since there was poor correlation between neutralising antibody and the MACRIA result, suggesting that different antigens are concerned, it would not be surprising if enterovirus infections sometimes boosted the neutralising antibody titre without affecting the MACRIA result and vice versa.

The coxsackie B MACRIA as described is of limited value as a routine diagnostic test because the heterotypic responses are unpredictable in individual patients. It may, however, prove useful for studying specific conditions such as diabetes or heart disease, where large numbers can be studied with appropriate controls.

The test might be improved in two ways. The antigen used in the MACRIA was unpurified, and it is possible that the specificity could be improved with either purified whole virus or viral polypeptides. Although this should be investigated in detail, this would entail the use of many different purified reagents and would be unsuitable for routine diagnostic use. An alternative approach would be to use multiple or disrupted antigens in order to detect group specific IgM. A test which detects enterovirus specific IgM antibody, although less useful for epidemiological purposes than a specific test, would certainly be of clinical value.

I would like to thank Dr EJ Bell, Dr DR Gamble, Dr MH Hambling, and Dr GBB White for providing sera for this study. 


\section{References}

' Schmidt NJ, Lennette EH, Dennis J. Characterisation of antibodies produced in natural and experimental Coxsackievirus infection. J Immunol 1968;100:99-106.

${ }^{2}$ Minor TE, Helstrom PB, Nelson DB, D' Alessio DJ. Countercurrent immunoelectrophoresis test for immunoglobulin $\mathbf{M}$ antibodies to group B Coxsackievirus. J Clin Microbiol 1979;9:503-6.

${ }^{3}$ El Hagrassy MMO, Banatvala JE, Coltart DJ. Coxsackie B virus specific IgM responses in patients with cardiac and other diseases. Lancet 1980;ii:1160-2.

4 Salacinski P, Hope J, McLean C, Clement-Jones V, Price J, Lowry PJ. A new simple method which allows theoretical incorporation of radio-iodine into proteins and peptides without damage. $J$ Endocrinol 1979;81:131P.

${ }^{5}$ Giraldi AJ, Hummeler K, Olshin I. Studies of the routine laboratory diagnosis of Coxsackie group B virus infections. I. The application of tissue culture procedures. $J$ Lab Clin Med 1957;50:526-33.

- Schmidt NJ, Dennis J, Hagens SJ, Lennette EH. Studies on the antibody responses of patients infected with $\mathrm{ECHO}$ viruses. Am J Hyg 1962;75:168-82.

${ }^{7}$ Schmidt NJ, Dennis J, Lennette EH. Antibody responses of
Rhesus (Macaca mulatta) monkeys experimentally infected with Coxsackie viruses of group B and group A type 9. II. Heterotypic antibody responses to echoviruses, polioviruses and reovirus type 1.J Immunol 1967;98:1060-6.

${ }^{8}$ Schmidt NJ, Magoffin RL, Lennette EH. Association of group B coxsackieviruses with cases of pericarditis, myocarditis, or pleurodynia by demonstration of immunoglobulin $\mathbf{M}$ antibody. Infect Immun 1973;8:341-8.

${ }^{9}$ Dorries R, Ter Meulen V. Specificity of IgM antibodies in acute human Coxsackie B infections, analysed by indirect solid phase enzyme immunoassay and immunoblot technique.J Gen Virol 1983;64:159-67.

${ }^{10}$ Morgan-Capner P, McSorley C. Antibody capture radioimmunoassay (MACRIA) for Coxsackie virus B4 and B5specific IgM. J Hyg (Camb) 1983;90:333-49.

" King ML, Shaikh A, Bidwell D, Voller A, Banatvala JE. Coxsackie-B-virus-specific IgM responses in children with insulin-dependent (Juvenile-onset; type 1) diabetes mellitus. Lancet 1983; i: 1397-9.

Requests for reprints to: Dr SF Pugh, Public Health Laboratory, University Hospital, Queen's Medical Centre, Nottingham NG7 2UH, England. 